\title{
Parametric clustering of cities
}

\author{
Nataliya Muromtseva ${ }^{1, *}$, Tatiana Simankina ${ }^{1}$ and Irina Alpackaya ${ }^{2}$ \\ ${ }^{1}$ Peter the Great St. Petersburg Polytechnic University, Civil Engineering Institute, 195251 \\ Polytechnicheskaya 29, St. Petersburg, Russian Federation \\ ${ }^{2}$ Moscow State University of Civil Engineering, 26, Yaroslavskoeshosse, 129337, Moscow, Russia
}

\begin{abstract}
The article analyzes the master plans and functional areas of 42 cities from different federal districts of the Russian Federation. To identify the dependencies between the characteristics of localities and the allocation of functional zones in them, the data clustering method was applied. Also criteria for clustering were identified - these are quantitative characteristics that are universal for various localities: total area of a locality, population, population density and gross regional product. With these criteria clustering was carried out using the software package «Deductor», based on algorithms of neural network modeling. Self-organizing Kohonen maps (SOM) were used to visualize the obtained data. As a result of the clustering the connection between the characteristics of localities and the ratio of functional zones in them is revealed.
\end{abstract}

\section{Introduction}

Most of modern scientific research in the field of functional purpose of territories is focused on the study of territorial zoning in general [1-4]. With regard to questions of the optimal ratio of functional zones, it should be noted that attention is not almost paid to them. Some researchers consider only the theoretical aspects of zoning, in particular, the preparation of territory planning documentation, and do not provide methods by which it would be possible to assess the relative position of the functional zones in specific localities [5-8].

The data clustering method considered in this work was applied in a number of works and used to assess the transport infrastructure of the city, housing stock, investment and social attractiveness of urban areas, and to draw up a schedule of building repairs [9-13].

In urban planning correct area ratio and mutual arrangement of city's functional areas are very important. Proper functional zoning of territories has economic and social advantages over the free placement of elements. The economic advantages are the opportunity to save urban areas, to minimize the cost of building all types of communications and to carry out landscaping. Social advantages include reducing the burden on the natural environment of the city and improving the living conditions of the population.

In conditions of urban population growth functional zoning significantly affects approaches to solving the problems of urban development, allows creating a balanced and comfortable living space. In this connection, the aim of the work is formation of functional

\footnotetext{
*Corresponding author: n.muromtseva@mail.ru
} 
zones clusters and finding the connection between the characteristics of localities and the ratio of functional zones in them.

\section{Materials and methods}

For many decades the fundamental idea for city planning was clear differentiation between the main functions of human life: work, housing and leisure. This is reflected in methodology of functional zoning, which according to Russian SP 42.13330.2016 «Townplanning. Planning and development of urban and rural settlements» implies a separation of the city into three main areas: residential, industrial, landscape-recreational and other territories. There are zones of various functional purposes within these territories.

Functional zones defined by master plan of locality obey the certain patterns that reflect various aspects of locality's formation. This affects parameters, such as: number of zones, possible territorial ratio of zones, mutual location, etc.

In this paper master plans of 42 large and largest cities of the Russian Federation from different federal districts were analyzed, where number of functional zones is mostly from 7 (Voronezh) to 10 (Krasnodar, Novosibirsk). As a result, we can distinguish the main functional areas into which the territory of the Russian Federation cities is divided (table 1).

Table 1. Functional zones of the Russian Federation cities.

\begin{tabular}{|l|c|}
\hline \multicolumn{1}{|c|}{ Functional zones } & Designation \\
\hline Housing zones & $\mathrm{H}$ \\
\hline Public and business zones & $\mathrm{PB}$ \\
\hline Industrial zones & $\mathrm{I}$ \\
\hline Zones of transport and engineering infrastructure & $\mathrm{TE}$ \\
\hline Recreational zones & $\mathrm{R}$ \\
\hline Agricultural zones & $\mathrm{A}$ \\
\hline Zones of special purpose & $\mathrm{S}$ \\
\hline Other territories & $\mathrm{O}$ \\
\hline
\end{tabular}

The ratios of the functional zones in the Russian Federation cities (as a percentage of the city's total area) are shown in Figures 1 and 2, the designations of the functional zones are given in accordance with Table 1.

The most balanced in terms of the ratio of functional zones are St. Petersburg and Kaliningrad (figure 1). 

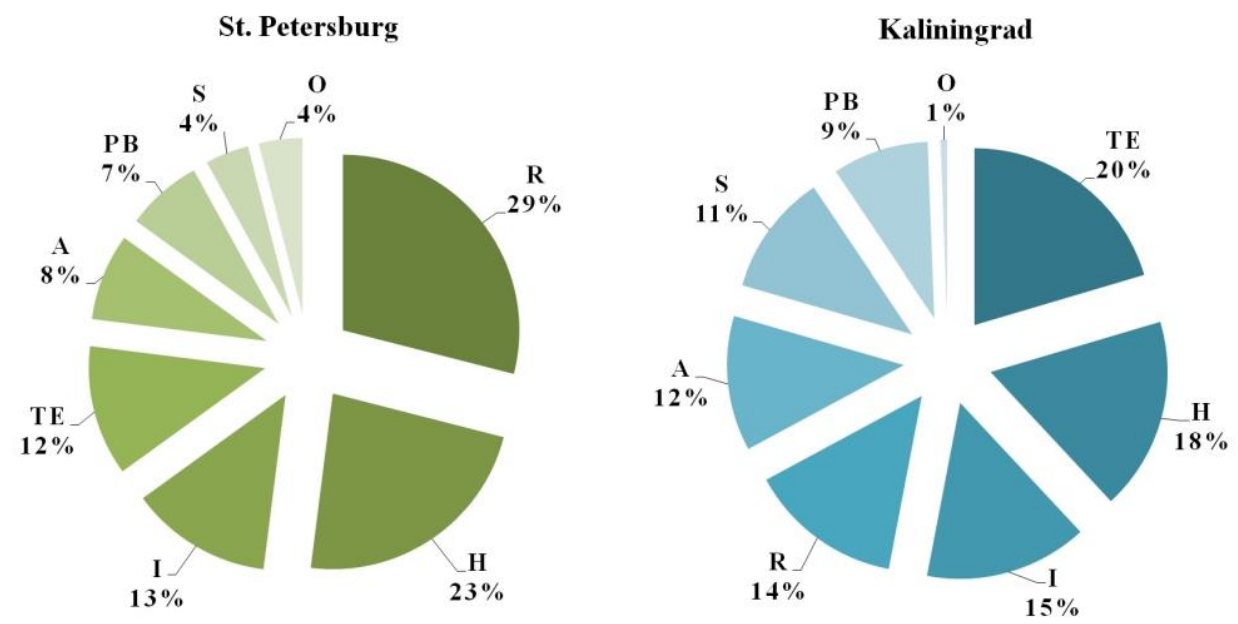

Fig. 1. The ratio of functional zones in St. Petersburg and Kaliningrad.

The recreational zone in Vladivostok and Voronezh is significantly superior to other zones (figure. 2).
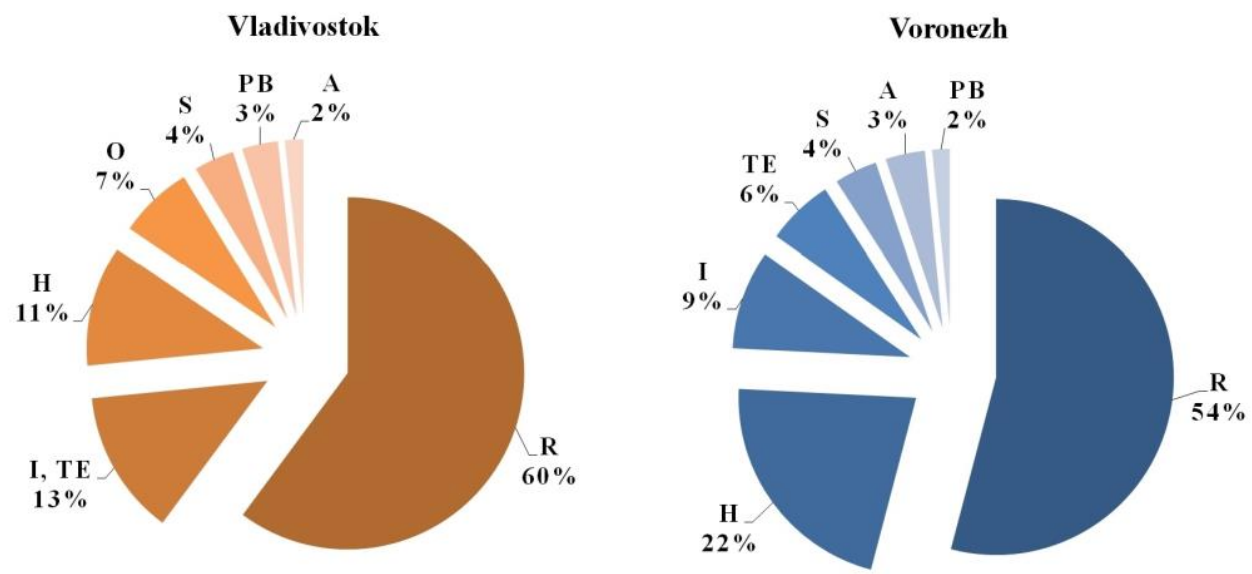

Fig. 2. The ratio of functional zones in Vladivostok and Voronezh.

To determine the best option for the correlation and mutual placement of functional zones in a particular locality, first of all, it is necessary to identify the influence of the localities characteristics on the zones allocation in them.

As these dependencies search method, data clustering method may be applied. An instrument realizing these goals is the software package «Deductor», based on algorithms of neural network modeling. One of the ways of data visualization and generalization used in this package is SOM (Kohonen self-organizing maps) [11, 14-15].

To develop functional zones clustering method, criteria on which clustering will be implemented need to be specified. Such criteria may be various characteristics of localities, for example: economic and geographical position, population size and density, total area, level of economic development, climate zone, city-forming function, etc. 
Because quantitative characteristics are the most universal indicators, for emerging method based on analysis of functional zones in 42 cities the following criteria of localities were selected:

- total area of the locality;

- population;

- population density;

- gross regional product.

\section{Results and discussion}

Based on selected criteria data clustering of 42 localities carried out. The results are several options of functional zones clusters (figure 3).

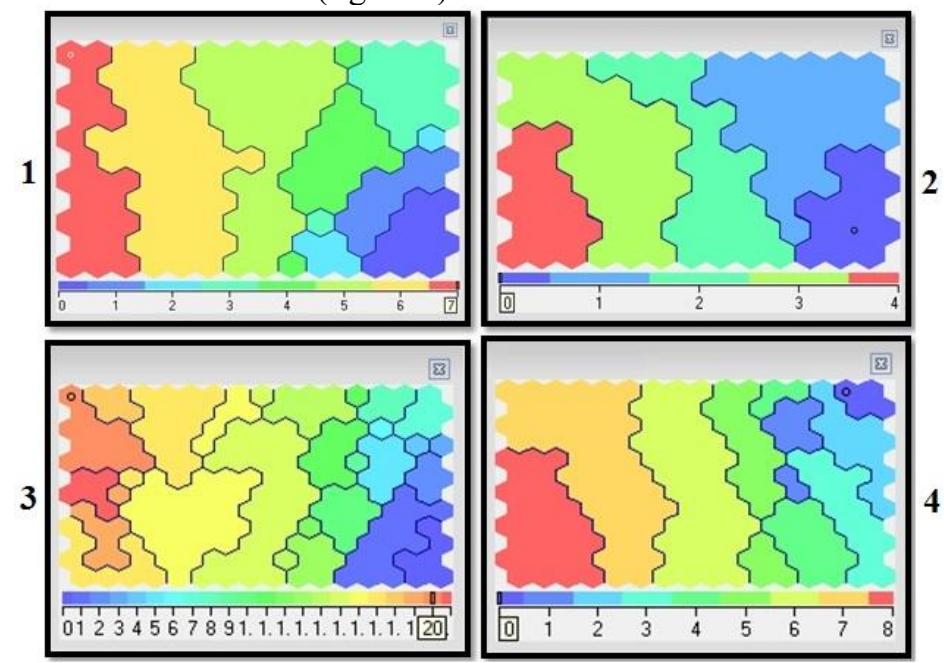

Fig. 3. Cluster options created in «Deductor».

The most convenient for analysis is the option with the least number of clusters - option 2 (figure 4).

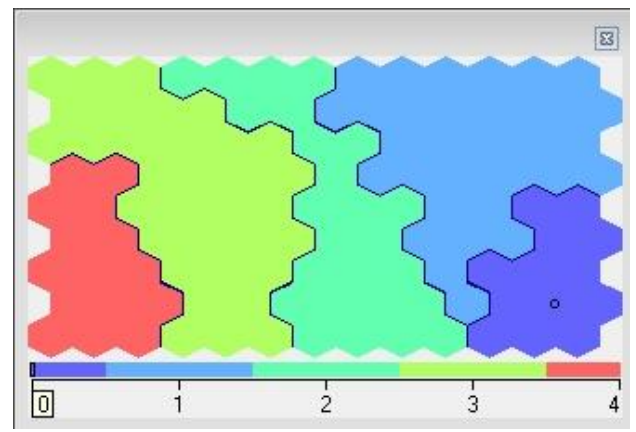

Fig. 4. Clusters of functional zones.

The analysis of the obtained clusters revealed a connection between the selected criteria and functional zones in cities.

So, for example, for the million-plus cities of the Volga, Ural, Siberian and Far Eastern Federal Districts the predominance of industrial and zones of special purpose is characteristic (table 2). 
Table 2. Characteristics of the cluster 1 .

\begin{tabular}{|l|l|}
\hline \multicolumn{1}{|c|}{ Characteristic } & \multicolumn{1}{c|}{ Value } \\
\hline Federal District & Volga, Ural, Siberian, Far Eastern \\
\hline City classification & The largest (over 1 million people) \\
\hline Total area & $50-80$ thousand ha \\
\hline Population & $1053-1200$ thousands of people \\
\hline Population density & $12-24$ persons per hectare \\
\hline Gross regional product & 204-453 thousand rubles per person \\
\hline Prevailing functional zones & $\begin{array}{l}\text { Zones of special purpose (30-54\% of } \\
\text { the locality total area), industrial zones } \\
\text { (5-23\% of the locality total area) }\end{array}$ \\
\hline Examples of localities & Chelyabinsk, Perm, Omsk \\
\hline
\end{tabular}

For the large cities of the Central, North-Western and Southern districts the prevalence of recreational and housing zones is characteristic (table 3 ).

Table 3. Characteristics of cluster 2.

\begin{tabular}{|l|l|}
\hline \multicolumn{1}{|c|}{ Characteristic } & \multicolumn{1}{c|}{ Value } \\
\hline Federal District & Central, Northwest, South \\
\hline City classification & Large (250-500 thousands of people) \\
\hline Total area & $11-22$ thousand ha \\
\hline Population & $275-482$ thousands of people \\
\hline Population density & $20-32$ persons per hectare \\
\hline Gross regional product & $279-951$ thousand rubles per person \\
\hline Prevailing functional zones & $\begin{array}{l}\text { Housing zones (12-42\% of the total } \\
\text { locality area), recreational zones (5- } \\
36 \% \text { of the total locality area) }\end{array}$ \\
\hline Examples of localities & Rostov-on-Don, Oryol \\
\hline
\end{tabular}

\section{Conclusions}

As a result, in this paper master plans of 42 Russian cities located in different federal districts were analyzed. 
1. The analysis of the Russian Federation cities revealed main functional zones, into which territories of the localities are divided.

2. The analysis of master plans revealed, that functional zoning in the cities has a similar structure, but there has been a difference of functional zones ratio by area.

3. Characteristics of localities affecting on the territorial balance and allocation of functional zones were defined - these are total area of the locality, population, population density and gross regional product. These characteristics served as criteria for clustering.

4. In this paper data clustering method applied, that has made it possible to indicate connection between characteristics of localities and allocation of functional zones in them.

\section{References}

1. O. Popova, M. Perekopskaya, G. Godunova, MATEC Web Conf. 170, 02012 (2018). https://doi.org/10.1051/matecconf/201817002012

2. H. Yin, F. Kong, X. Yang, P. James, I. Dronova, Cities, 81, 214-229 (2018). https://doi.org/10.1016/j.cities.2018.04.010

3. R. Zandi, M. Zanganeh, E. Akbari, J. Urban Manag. 8(3), 342-354 (2019). https://doi.org/10.1016/j.jum.2019.09.002

4. J. Porta, J. Parapar, R. Doallo, F.F. Rivera, I. Santé, R. Crecente, Comput. Environ. Urban. Syst. 37, 45-58 (2013). https://doi.org/10.1016/j.compenvurbsys.2012.05.003

5. H. Rhee, S. Yu, G. Hirte, Reg. Sci. Urban. Econ, 44, 82-93 (2014). https://doi.org/10.1016/j.regsciurbeco.2013.12.002

6. R. Raman, U.K. Roy, Land Use Policy 88, 104102 (2019). https://doi.org/10.1016/j.landusepol.2019.104102

7. A.M. Hersperger, E. Oliveira, S. Pagliarin, G. Palka, P. Verburg, J. Bolliger, S. Grădinaru, Glob. Environ. Change, 51, 32-42 (2018). https://doi.org/10.1016/j.gloenvcha.2018.05.001

8. E. Talen, L. Anselin, S. Lee, J. Koschinsky, Landsc. Urban. Plan, 152, 27-38 (2016). https://doi.org/10.1016/j.landurbplan.2016.04.002

9. O. Popova, E. Kuznecova, T. Sazonova, MATEC Web Conf., 170, 05006 (2018). https://doi.org/10.1051/matecconf/201817005006

10. O. Popova, T. Simankina, V. Lukinov, MATEC Web Conf., 106, 01013 (2017). https://doi.org/10.1051/matecconf/201710601013

11. T. Simankina, O. Popova, Maps. Appl. Mech. Mater., 725-726, 1057-1062 (2015). https://doi.org/10.4028/www.scientific.net/AMM.725-726.1057

12. O. Popova, J. Glebova, A. Pustovgar, E3S Web Conf., 33, 02032 (2018). https://doi.org/10.1051/e3sconf/20183302032

13. T. Simankina, O. Popova, Repair. Appl. Mech. Mater., 584-586, 1944-1950 (2014). https://doi.org/10.4028/www.scientific.net/AMM.584-586.1944

14. J. Qi, H. Liu, X. Liu, Y. Zhang, Comput. Environ. Urban. Syst., 76, 11-23 (2019). https://doi.org/10.1016/j.compenvurbsys.2019.03.002

15. A. A. Hameed, B. Karlik, M.S. Salman, G. Eleyan, Knowl. Based Syst. 171, 25-36 (2019). https://doi.org/10.1016/j.knosys.2019.01.011 